UDC 577.2+616-006.441

\title{
EFFECT OF NITRIC OXIDE DONOR ON VIABILITY OF HUMAN LEUKEMIC CELLS UPON ARGININE DEPRIVATION
}

\author{
O. I. Chen ${ }^{1,2}$, L. S. Lyniv ${ }^{1}$, N. I. Igumentseva1, \\ M. L. Barska ${ }^{1}$, N. O. Sybirna ${ }^{1,2}$, O. V. Stasyk ${ }^{1}$ \\ ${ }^{1}$ Institute of Cell Biology, NAS of Ukraine, 14-16, Drahomanov St., Lviv 79005, Ukraine \\ ${ }^{2}$ Ivan Franko National University of Lviv, 4, Hrushevskyi St., Lviv 79005, Ukraine \\ e-mail: stasyk@cellbiol.Iviv.ua
}

Some types of tumor cells are unable to synthesize arginine from its precursors. They exhibit growth inhibition and decreased viability in vitro and in vivo under enzymatic arginine deprivation. However, prolonged arginine starvation in human may cause vasoconstriction and thrombosis due to the deficit of arginine derivative, nitric oxide (NO), as vasodilator and disaggregant. This problem can be overcome via supplementation with exogenous NO-donors in vivo, which, in turn, may produce either, pro-apoptotic or anti-apoptotic specific effects on cancer cells under arginine restriction.

In this study we elucidated the effect of exogenous NO donor, sodium nitroprusside (SNP) on the viability of human Jurkat leukemic cells under arginine deprivation in vitro. We observed that arginine deprivation suppressed cell proliferation and led to a rapid decrease in cell viability concomitant with progression of apoptosis. According to SNP IC50 determination and apoptosis assays, NO-donor at physiological concentration did not promote survival of tumor cells in arginine-free medium. Moreover, SNP cytotoxicity for Jurkat cells was increased upon arginine withdrawal, suggesting that application of $\mathrm{NO}$ donor in vivo may potentially enhance the therapeutic effect of arginine deprivation.

Key words: arginine deprivation, nitric oxide, sodium nitroprusside, apoptosis, leukemic cells.

Metabolic enzymotherapy based on recombinant arginine-degrading enzymes harbors a good potential to be developed into efficient anticancer treatment. Recent studies demonstrated its effectiveness in inhibiting growth and decreasing viability of cancer cells in vitro and in vivo $[3,9,11,16]$. Potentially sensitive to this treatment cancer cells are those that are unable to synthesize arginine from ornithine or citrulline (due to the deficiency of enzymes of urea cycle, argininosuccinate synthetase (ASS) and ornithine transcarbamoylase (OTC) [5, 7]. Among types of tumors auxotrophic for arginine and fully dependent on its exogenous supply are many those, for which currently no efficient cure exists, such as melanomas, hepatocarcinomas, mesotheliomas, renal 
and prostate carcinomas [7, 13, 16, 21]. Recently, human leukemic cells were demonstrated to be sensitive to arginine starvation in vitro [11]. Although the molecular mechanism that triggers apoptosis in tumor cells under arginine deprivation has not been yet elucidated, we recently demonstrated that alterations in arginine metabolism are not the main cause, and aberrant cell cycle regulation is most probably implicated in this process $[2,13,18]$.

Arginine, besides being involved in protein synthesis, has other versatile functions in the organism as a single precursor of many important metabolites, such as polyamines, agmatine and nitric oxide (NO) [14]. Although arginine starvation is well tolerated, its depletion in organism may nevertheless cause deficit in its metabolic products and result in some unwanted side effects. For instance, NO, as a signalling molecule, regulates various physiological and pathophysiological processes, such as vascular functions (angiogenesis, blood flow, vascular permeability, leukocyte-endothelial interaction, platelet aggregation), neurological functions (neurotransmission and memory formation) and immune functions (cytostasis and cytolysis) [8]. Thus, arginine limitation in humans may lead to hart disorder, vasoconstriction and thrombosis due to the deficit of $\mathrm{NO}$ as vasodilator and disaggregant. Potentially, application of exogenous NO donor in vivo could diminish some side effects of arginine deprivation given that it does not substantially improve tumor cell viability upon arginine withdrawal. In this work we aimed to elucidate whether exogenous NO donor will affect viability of human leukemic cells upon arginine deprivation, taking into account that NO was shown to elicit both pro- and antiapoptotic effects on different cell models in vitro [8, 12, 17].

\section{MATERIALS AND METHODS}

\section{Cell lines and cell culture}

Human leukemic Jurkat cells used in this study were obtained from Cedar Sinaj Medical Center (Los Angeles, USA). J774.2, murine macrophage cell line was obtained from William Harvey Institute (London, England).

Tumor cells were cultured in RPMI-1640 medium (HyClone Laboratories, USA) supplemented with 10\% FBS (fetal bovine serum) (PAA Laboratories $\mathrm{GmbH}$, Austria), $300 \mathrm{mg} / \mathrm{l}$ glutamine and $50 \mu \mathrm{g} / \mathrm{ml}$ gentamycin (Sigma-Aldrich, USA). The cells were subcultivated every $2-3$ days and split in a 1:3 ratio. In all experiments the medium was formulated such that it could either contain $0.4 \mathrm{mmol} / \mathrm{l}$ arginine (complete arginine-rich medium, CM) or be arginine-free (AFM). Experimental media were supplemented with $5 \%$ dialysed FBS (HyClone Laboratories, USA). Cells were used in the exponential growth phase in all experiments.

\section{Trypan Blue Dye Exclusion Assay}

The kinetic of cells growth was determined by trypan blue exclusion test. Briefly, cells were plated in 96-well plates at a density of $2-3^{*} 10^{4}$ cells/well following overnight incubation in RPMI 1640 medium. The culture medium was discarded and the cells were washed with phosphate-buffered saline (PBS) and a fresh control or tester medium with different doses of SNP was added to each well and incubated for selected periods of time at $37^{\circ} \mathrm{C}$ and in a humidified $5 \% \mathrm{CO}_{2}$. The cells were resuspended and aliquots of cells were mixed with the trypan blue dye solution (Sigma-Aldrich, USA) to its

ISSN 1996-4536 • Біологічні Студії / Studia Biologica • 2011 • Том 5/№2 • С. 17-28 
final concentration of $0.05 \%$. The cells were counted on a hemocytometer by light microscopy and stained blue cells were considered and calculated as "non-viable”. The amount of SNP needed to kill $50 \%$ of the cells in a culture was defined as the inhibitory concentration (IC50). Experiments were performed in duplicate parallels and repeated at least three times.

\section{Measurement of NO production}

The amounts of NO released by NO donor SNP or by an IFN- $\gamma$ - and LPS-stimulated macrophage murine cell line $\mathrm{J} 774.2$ were estimated by measuring the accumulation of the terminal metabolite of $\mathrm{NO}$, nitrite $\left(\mathrm{NO}_{2}^{-}\right)$, in the culture medium by using the Griess method as previously described [10]. SNP was dissolved in cell culture medium (CM or AFM) containing $5 \%$ dialyzed FBS and incubated at $37^{\circ} \mathrm{C}, 5 \% \mathrm{CO}_{2}$ for different period of time in 24-well plates. Briefly, a $500 \mu \mathrm{L}$ aliquot of cell culture medium was mixed with $500 \mu \mathrm{L}$ of Griess reagent ( $1 \mathrm{vol}$ of $0.2 \%$ naphthylethylenediamine dihydrochloride in distilled water plus 1 vol of $2 \%$ p-aminobenzenesulfonamide in $5 \%$ of phosphoric acid). The mixture was incubated for $10 \mathrm{~min}$ at room temperature. Absorbance at $540 \mathrm{~nm}$ was measured spectrophotometrically. A scalar dilution of $\mathrm{NaNO}_{2}$ was used as a standard. Results were expressed as concentration of $\mathrm{NO}_{2}^{-}$.

\section{Western blot analysis}

Cells were lysed in extraction buffer containing $10 \mathrm{mM}$ Tris- $\mathrm{HCl}(\mathrm{pH} 7.5), 150 \mathrm{mM}$ $\mathrm{NaCl}, 1 \% \mathrm{NP}-40,5 \mathrm{mM}$ EDTA, $50 \mathrm{mM} \mathrm{NaF}, 1 \mathrm{mM} \mathrm{Na}_{3} \mathrm{VO}_{4}, 5 \mathrm{mM}$ benzamidine, $1 \mathrm{mM}$ PMSF, $10 \mathrm{mg} / \mathrm{ml}$ aprotinin, $10 \mathrm{mg} / \mathrm{ml}$ leupeptin, $1 \mathrm{mg} / \mathrm{ml}$ pepstatin) at $4^{\circ} \mathrm{C}$ for $20 \mathrm{~min}$. Protein content in the extracts that were obtained was determined according to Peterson's method [15]. For western blot analysis proteins were separated on $10 \%$ SDSPAGE and transferred onto a PVDF membrane (Millipore Corporation, USA). The membranes were blocked in 5\% non-fat dried milk in PBS containing $0.05 \%$ Tween-20 and incubated with primary antibodies specific for the cleaved polyADP ribosyl polymerase (PARP; Cell Signaling Technologies, USA) and $\beta$-actin (Sigma, USA) as the loading control. Secondary goat anti-mouse and anti-rabbit (Millipore Corporation, USA) antibodies and an enhanced chemiluminescence system (Millipore Corp., USA) were used for the detection of immunoreactive proteins.

\section{Apoptosis Detection Assay}

Apoptosis detection was performed as described [6]. Cells were resuspended in Ringer solution with calcium ions to a final concentration of $1 \cdot 10^{6} / \mathrm{ml}$. Then $5 \mu \mathrm{l}$ of cells suspension was mixed with $5 \mu \mathrm{L}$ of Annexin V-FITC (Sigma, USA, final concentration $3 \mu \mathrm{g} / \mathrm{mL}$ ) followed by propidium iodide (final concentration $0.5 \mu \mathrm{g} / \mathrm{mL}$ ) as a counter stain. The cells were then incubated at room temperature for 5-15 $\mathrm{min}$ in the dark. Finally, the cells were covered with a coverslip and examined by fluorescent microscopy. The percentage of apoptotic cells was calculated using a ImageJ software.

\section{Statistical analysis}

Each experiment was performed at least three times and data are presented as the mean \pm SEM. The Student's unpaired t-test was used to compare the means of two groups. Differences were considered statistically significant when $p>0.95$. 


\section{RESULTS}

3.1. Jurkat cells are sensitive to arginine deprivation in vitro and cannot utilize arginine precursors.

In our experiments, human Jurkat lymphoblastic leukemia cells were used as a model for acute T-cell leukaemia. We studied cell growth and cell viability both in control arginine-rich medium (CM), arginine-free medium (AFM), and in AFM supplemented with metabolic precursors of arginine - citrulline and ornithine, which utilization depends on the status of arginine anabolic enzymes, ASS and OTC, respectively. The number of cells was evaluated by trypan blue dye exclusion assay every $24 \mathrm{~h}$ till $96 \mathrm{~h}$ of incubation. We observed that arginine deprivation strongly inhibited proliferation of Jurkat cells (Fig. $1, A)$ under chosen experimental conditions. At the same time, the number of dead cells increased time-dependently under arginine deprivation (Fig. 1, B).

Supplementation with $0.4 \mathrm{mM}$ citrulline and ornithine into cell culture medium had no effect on cell proliferation. This observation suggests that Jurkat cells are auxotrophic for arginine, at least in vitro, and cannot convert ornithine or citrulline to arginine. In fact, all previously tested by us human tumor cells appeared to be OTC-deficient, whereas ASS expression level varied between different cell lines and positively correlated with the ability of exogenous citrulline to support cell growth upon arginine withdrawal [2].

We also analyzed the ability of Jurkat cells to recover their growth after different periods of arginine depletion (24 to $96 \mathrm{~h}$ ). Cells were cultured in arginine-free medium (AFM) for appropriate time, then the medium was changed for the complete argininesupplemented medium (CM) and cells were allowed to grow for additional $72 \mathrm{~h}$. Our results demonstrated that Jurkat cells were not able to restore growth already after $48 \mathrm{~h}$ of arginine starvation and this ability decreased time-dependently (Fig.1, C).

\subsection{Arginine deprivation increases NO cytotoxicity in Jurkat cells.}

SNP is one of the most widely used agents for the management of hypertensive emergencies, and has been in clinical use for several decades [12, 20]. We utilized SNP as a NO donor to examine the viability and growth potential of malignant cells upon combination of arginine deprivation and exogenous nitric oxide releasing compound.

First, SNP cytotoxic concentration (the concentration that causes death of $50 \%$ cells, IC50) for Jurkat cells upon different culture conditions was determined. For this, cells were treated with several concentrations of $\operatorname{SNP}(0,0.001,0.01,0.1,1$ and $10 \mathrm{mmol} / \mathrm{l})$ in both arginine-rich and arginine-free media. We observed that SNP strongly inhibited the viability of Jurkat cells in a concentration and time-dependent manner in complete and arginine-free media. At 24, 48, and $72 \mathrm{~h}$ of incubation, the estimated SNP IC50 in CM were 3.0, 0.5 and $0.1 \mathrm{mM}$ respectively (Fig. 2, A). In AFM, the SNP IC50 for Jurkat cells was significantly lower relative to IC50 in arginine-rich medium: 0.7, 0.1 and $0.02 \mathrm{mM}$, corresponding to 24,48 , and $72 \mathrm{~h}$ of incubation (Fig. 2, B). Therefore, exogenous NO donor at very low concentrations negatively affects Jurkat cells viability and arginine deprivation elevates its cytotoxicity.

Based on IC 50 data for Jurkat cells, we measured the rate of SNP decomposition in cell culture medium at two different concentrations, 0.1 and $1 \mathrm{mM}$. First, we compared kinetics of nitrite levels released from $0.1 \mathrm{mM}$ SNP in CM and AFM and found them

ISSN 1996-4536 • Біологічні Студії / Studia Biologica • 2011 • Том 5/№2 • C. 17-28 

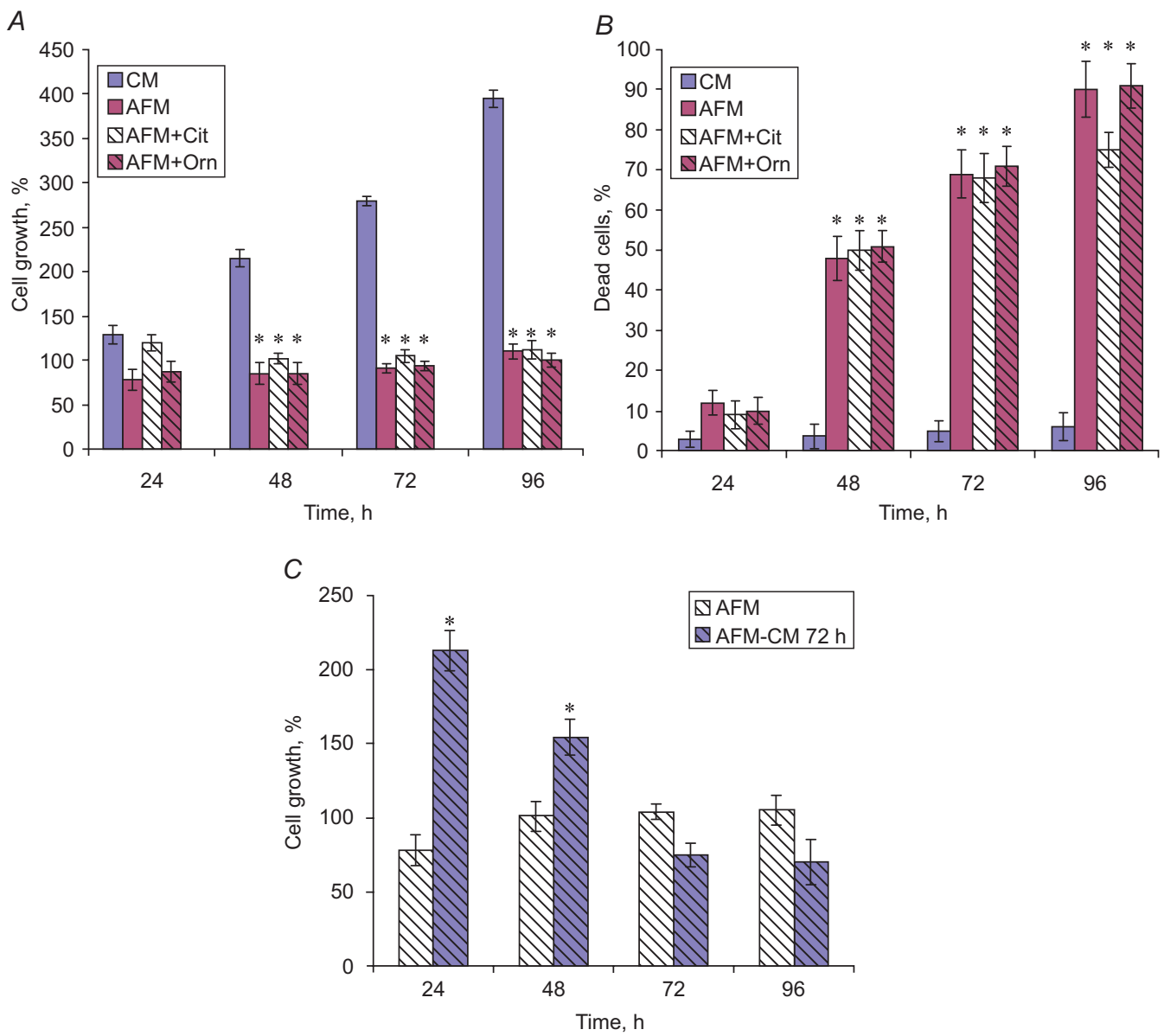

Fig. 1. Dynamics of cell growth $(A)$ and number of dead cells $(B)$ of Jurkat cells during cultivation in complete medium (CM), arginine-free medium (AFM), and arginine-free medium supplemented with citrulline $0.4 \mathrm{mM}$ (AFM+Cit) or ornithine, $0.4 \mathrm{mM}$ (AFM+Orn). (C) - Dynamics of growth restoration (AFM-CM $72 \mathrm{~h}$ ) of Jurkat cells after different periods of arginine deprivation (24 to 96 hours). After the indicated periods of treatment, the medium was changed to the complete arginine-rich medium (CM), and cells were allowed to grow for additional $72 \mathrm{~h}$. Cell numbers were determined by the trypan blue exclusion test, ${ }^{*} \mathrm{p} \leq 0.05$ compared with the untreated cells

Рис. 1. Динаміка росту клітин $(A)$ та кількість мертвих клітин $(B)$ клітинної лінії Jurkat протягом різного часу культивування на повному поживному середовищі (CM), середовищі без аргініну (AFM) та середовищі без аргініну з додаванням 0,4 мМ цитруліну (AFM+Cit) або 0,4 мM орнітину (AFM+Orn). (C) - динаміка відновлення росту (AFM-CM - 72 h) клітин Jurkat після різного часу голодування за аргініном $(24,48,72,96$ год). Після відповідного періоду голодування середовище замінювалося на повне і клітини культивувалися протягом 72 год. Кількість клітин визначали у тесті з трипановим синім, * $p \leq 0,05$ порівняно 3 контрольними клітинами

identical (data not shown). We also compared the nitrite levels released in the culture medium by $0.1 \mathrm{mM}$ and $1 \mathrm{mM}$ SNP and by J774.2 murine macrophage cells, stimulated with $1 \mathrm{mg} / \mathrm{ml}$ LPS plus $100 \mathrm{U} / \mathrm{ml}$ murine IFN-g. J774.2 cells are able to release NO in vitro and provide a realistic model for overproduction of $\mathrm{NO}$ under inflammatory process 

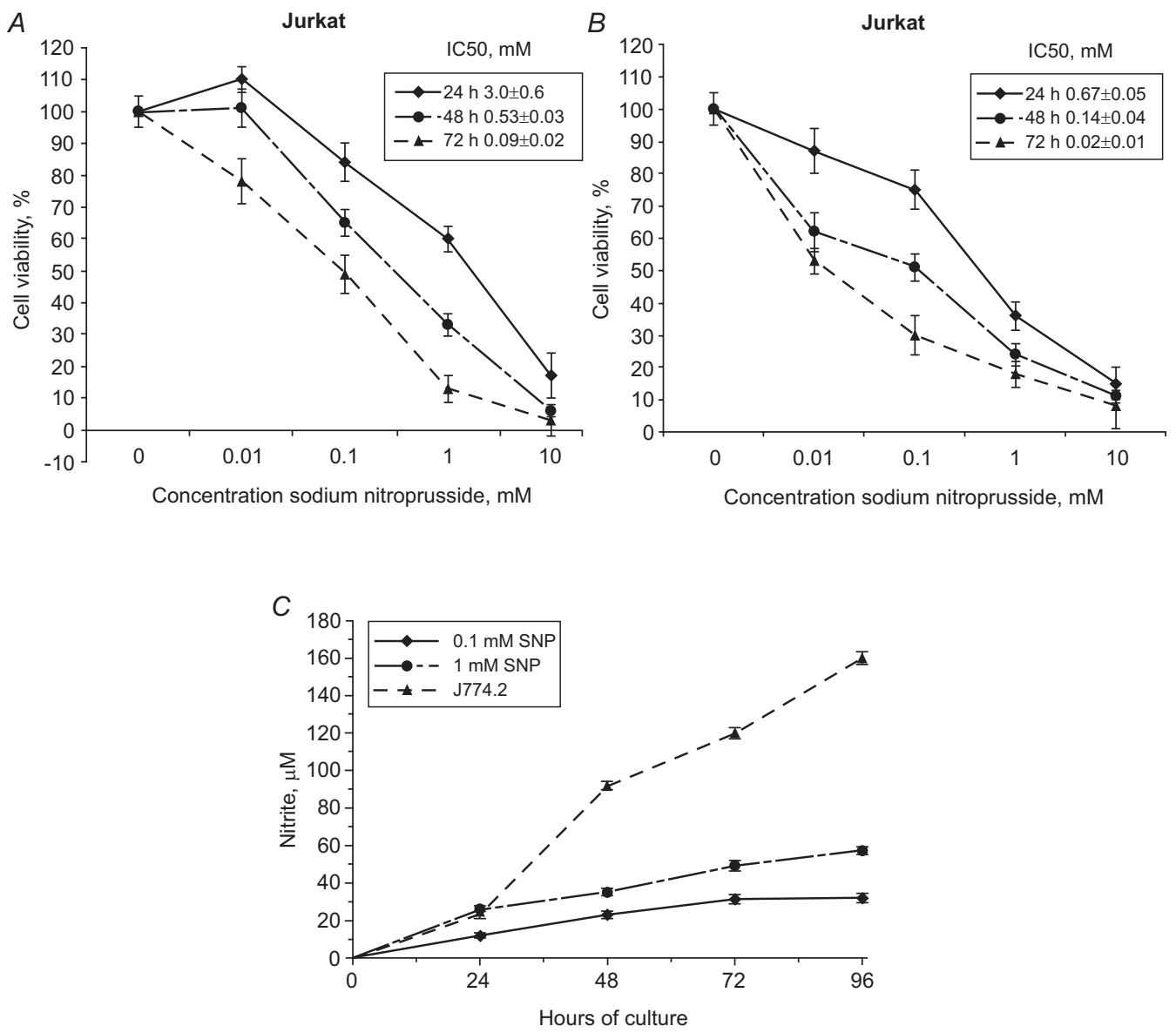

Fig. 2. Concentration- and time-dependent inhibition of Jurkat cells viability by sodium nitroprusside (SNP) in complete medium $(C M)-(A)$, and arginine-free medium $(A F M)-(B)$. Cells were treated with various concentrations of SNP as described in Materials and Methods. Cell viability and IC50 for SNP were determined at 24,48 , and $72 \mathrm{~h}$. Results represent means \pm SD of three experiments performed in triplicate. $(C)$ - Nitrite levels released into cell culture medium (CM or AFM) containing a nitric oxide donor - SNP ( 0.1 or $1 \mathrm{mM}$ ), or by into the medium from a culture of J774.2 macrophage cells stimulated with LPS $(10 \mu \mathrm{g} / \mathrm{ml})$ and IFN- $\gamma(10 \mathrm{nmole} / \mathrm{ml})$. At the indicated time points, an aliquot of the medium was collected and the nitrite concentration was determined by the Griess reaction technique. Results are representative of three independent experiments

Рис. 2. Концентраційно- і часозалежне інгібування життєздатності клітин Jurkat нітропрусидом натрію (SNP) на повному середовищі (CM) - (A) та середовищі без аргініну (AFM) - (B). Клітини піддавалися обробці різними дозами SNP, як описано у методах і матеріалах. Життєздатність клітин та IC50 для SNP визначали на 24, 48, та 72 год. (C) - швидкість вивільнення нітритів у культуральне середовище (CM або AFM) донором оксиду азоту - нітропрусидом натрію (SNP, 0,1 та 1 мM); та у культуральне середовище з клітин макрофагів J774.2, стимульованих ліпополісахаридом (LPS) у концентрації 10 мкг/мл та інтерфероном- (IFN- $\gamma$ ) у концентрації 10 нмоль/мл. Після відповідного часу культивування відбиралося культуральне середовище та визначався вміст нітритів реакцією з реактивом Грісса. Представлені результати трьох незалежних експериментів 
(detected as nitrite accumulation) [22]. A progressive accumulation of nitrite in the medium with J774.2 cells stimulated with LPS and IFN-g was observed, and it was significantly higher at $48 \mathrm{~h}$ relative to nitrite levels in the culture medium supplemented with $0.1 \mathrm{mM}$ and $1 \mathrm{mM}$ SNP (Fig. 2, C). This observation indicated that the selected concentrations of SNP released NO in amounts comparable with physiologically compatible levels [20].

\subsection{Combination of arginine deprivation with SNP does not counteract apoptotic} cell death in Jurkat cells.

We next examined whether a prolonged arginine deprivation induces apoptosis in Jurkat cells that may be concomitant to the observed decrease in their viability (Fig. 1). Indeed, we observed that the expression of the cleaved form of PARP protein (as an apoptotic marker) in Jurkat cell increased in a time-dependent manner (Fig. 3, A), starting from $12 \mathrm{~h}$ and reaching its maximum on $72 \mathrm{~h}$ of arginine starvation. Importantly, supplementation with $0,1 \mathrm{mM}$ SNP accelerated the first appearance of the cleaved PARP form suggesting that exogenous NO donor may potentially speed up the apoptotic cell death upon arginine deprivation. The above data were also confirmed by apoptosis assay in Jurkat cells under tested conditions via their double staining with fluorochromes Annexin V-FITC (binds to phosphatidylserine on membranes of apoptotic cells) and propidium iodide (Fig. 3, B). We observed no significant changes in the number of apoptotic Jurkat cells upon combined $48 \mathrm{~h}$-long treatment with arginine deprivation and exogenous SNP relative to the amino acid deprivation treatment alone (Fig. 3, C). The obtained results suggest that exogenous NO donor at physiological level does not negatively affect progression of apoptosis in arginine-deprived Jurkat cells and does not rescue their viability.

\section{DISCUSSION}

In this study we analyzed the effect of exogenous NO donor on the viability of human leukemic Jurkat cells under arginine deprivation. The aim of this work is substantiated by potential need to use NO donor in vivo as a compensatory agent to prevent vasodilatation caused by low NO levels upon treatment with recombinant arginine-degrading enzymes [4].

Jurkat cells were chosen as an experimental model. We demonstrated that these cells are auxotrophic for arginine as its precursors, ornithine and citrulline, are unable to support Jurkat cell proliferation upon arginine withdrawal (Fig. 1, A). Secondly, Jurkat cells appeared to be very sensitive to a single amino acid arginine deprivation and were unable to restore their proliferation when shifted to fresh complete medium already after 24 hours of arginine starvation (Fig. 1, C). When starved for arginine in a defined medium, which is a suitable model for the treatment with arginine-degrading enzymes $[11,16]$, viability of Jurkat cells progressively decreased (Fig. 1, B), and signs of apoptosis were evident (Fig. 3).

When exogenous NO donor is administered, one can expect various secondary effects on cell viability, as NO is a known signaling molecule implicated in cell survival and apoptosis $[12,17]$. In addition, NO-deficiency may be one of the possible causes of the decreased cell viability specifically under arginine deprivation (since arginine is a 
single NO precursor and substrate for NO-synthases), and exogenous NO donor could potentially rescue cell viability. We found, however, that this is not the case, at least in the particular Jurkat cell model.

We found that cytotoxic concentration (IC50) of NO donor, SNP, decreased dramatically for arginine-deprived cells relative to cells cultivated in the complete medium. Also, the amount of NO (estimated by nitrite accumulation in the medium), released by exogenous SNP at different tested concentrations, was comparable to that produced by the stimulated murine macrophage cells, suggesting that it is close to a physiological range (Fig. 3, C). We observed that SNP, at low $0.1 \mathrm{mM}$ dose, does not counteract

A

CM AFM AFM+SNP $0.1 \mathrm{mM}$

$\begin{array}{llllllllllll}6 & 12 & 24 & 48 & 72 & 96 & 6 & 12 & 24 & 48 & 72 & 96\end{array}$

Cleaved PARP $89 \mathrm{kDa}$

$\beta$-actin
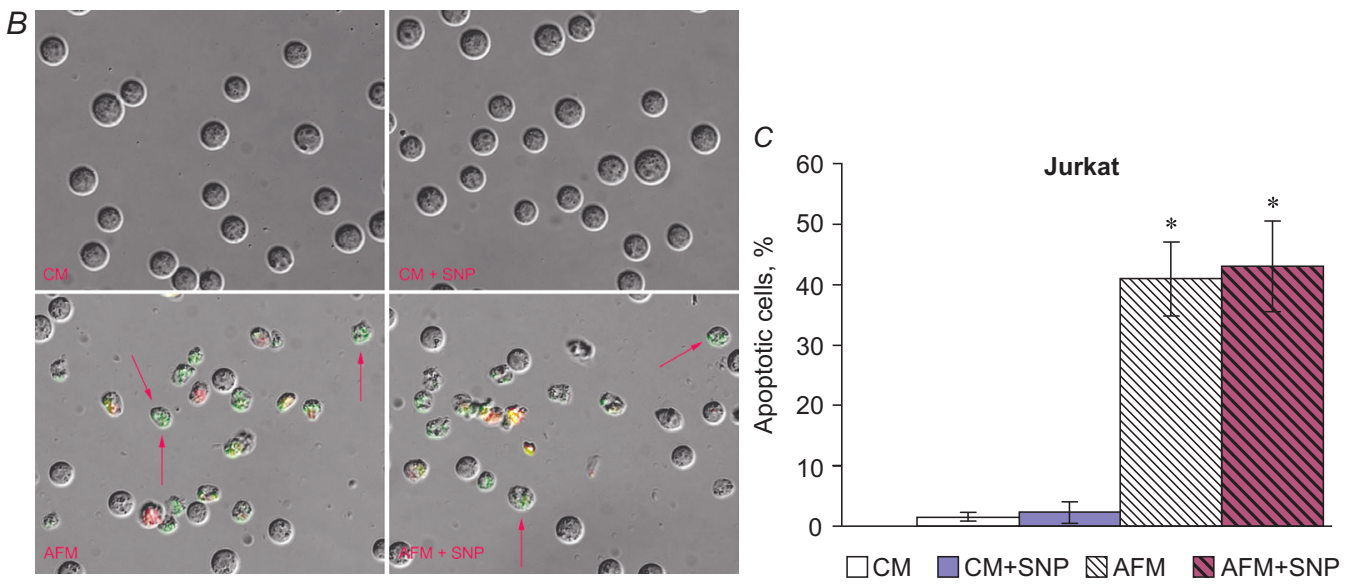

Fig. 3. A-Western blot analysis of the cleaved form of PARP protein in Jurkat cells cultured in arginine-free medium (AFM), or in AFM supplemented with sodium nitroprusside (SNP, $0.1 \mathrm{mM}$ ). CM - control cells, which were cultured in CM. $B$ - Merged image of Annexin $V$ fluorescence of apoptotic Jurkat cells: $\mathrm{CM}$ - control cells, cultured in the complete medium, CM+SNP - cells, cultured in CM with $0.1 \mathrm{mM}$ SNP, AFM - cells, cultured in AFM, AFM+SNP - cells, cultured in AFM with $0.1 \mathrm{mM} \mathrm{SNP.} \mathrm{(C)} \mathrm{-} \mathrm{The}$ effect of arginine deprivation and combined treatment with SNP on the viability of Jurkat cells upon 48 hours of treatment. Cells were stained with Annexin V and propidium iodide and analyzed in fluorescent microscopy as described in Materials and Methods, * $p \leq 0.05$ compared with untreated cells

Рис. 3. A - Вестерн-блот аналіз активованої форми білка PARP у клітинах лінії Jurkat, культивованих на середовищі без аргініну а також з додаванням 0,1 мМ нітропрусиду натрію. СМ - контрольні клітини культивовані на повному середовищі. $B$ - накладене зображення флуоресценції анексину V (зелене); CM - контрольні клітини, CM+SNP - клітини культивовані на повному середовищі з додаванням 0,1 мМ нітропрусиду натрію, AFM - клітини культивовані на безаргініновому середовищі, AFM+SNP - клітини культивовані на середовищі без аргініну з додаванням 0,1 мM нітропрусиду натрію. C - вплив голодування за аргініном з 0,1 мM SNP на апоптоз клітин лінії Jurkat після 48 год інкубації. Клітини фарбували Анексином V з прорідій йодидом і аналізували за допомогою фолуоресцентної мікроскопії, * $p \leq 0,05$ порівняно з контрольними клітинами

ISSN 1996-4536 • Біологічні Студії / Studia Biologica • 2011 • Том 5/№2 • С. 17-28 
apoptotic cell death in Jurkat cells triggered by arginine deprivation. Moreover, NO donor may even speed up the process. Based on these data, we also hypothesize that NO deficiency resulting from arginine deprivation is not the cause of high Jurkat cells sensitivity to arginine deprivation. This and other our studies on different cell models support the notion that not arginine metabolism but other cell response mechanisms must be involved in determining cell fate upon arginine starvation [2].

In summary, this work describes first pre-clinical in vitro studies for evaluation of the effect of SNP as a NO-donor on tumor cells under arginine deprivation. Our data suggest that exogenous NO donor may be potentially used as an adjuvant compensatory agent upon arginine deprivation, in particular, for leukemic cells sensitive to this treatment. It may be expected that application of NO donor in vivo may enhance anticancer potential of enzymotherapy based on arginine deprivation. Whether this holds for other tumor cells, for instance, cells of solid cancers, will be addressed in our next studies.

\section{CONCLUSION}

We elucidated the effect of exogenous nitric oxide donor, sodium nitroprusside (SNP), on the viability of human leukemic cells under arginine deprivation. We demonstrated that:

1. Human Jurkat cells are very sensitive to arginine deprivation in vitro and are auxotrophic for this amino acid.

2. Arginine deprivation significantly increased cytotoxicity of exogenous SNP for Jurkat cells.

3. NO-donor did not promote survival of tumor cells in arginine-free medium and did not counteract apoptotic mechanism, triggered in Jurkat cells by arginine withdrawal.

4. SNP can be recommended as a potential agent for adjuvant arginine deprivation-based therapy for some types of tumors.

\section{ACKNOWLEDGEMENTS}

This study was partially supported by the West Ukrainian BioMedical Research Center (WUBMRC) grant awarded to Lyniv L.S. We thank Dr. J.Marcinkiewich, JagielIonian University, Krakow, Poland for the generous gift of J774.2 murine macrophage cell line, and Prof. R. S. Stoika, Institute of Cell Biology, NAS of Ukraine for providing Jurkat T-cell line used in this study.

1. Bansal V., Rodriguez P., Wu G. et al. Citrulline Can Preserve Proliferation and Prevent the Loss of CD3 Chain Under Conditions of Low Arginine. JPEN, 2004; 28(6): 423-430.

2. Bobak Y.P., Vynnytska B.O., Kurlishchuk Y.V. et al. Cancer cell sensitivity to arginine deprivation in vitro is not determined by endogenous levels of arginine metabolic enzymes. Cell Biol. Int, 2010; 4: 1085-1090.

3. Cheng P.N., Lam T.L., Lam W.M. et al. Pegylated recombinant human arginase (rhArgpeg5000 mw) inhibits the in vitro and in vivo proliferation of human hepatocellular carcinoma through arginine depletion. Cancer Res, 2007; 67: 309-317.

4. Cheng N.M., Leung Y.C., Lo W.H.: US Patent No. 20050244398. 2005.

5. Delage B., Fennell D.A., Nicholson L. et al. Arginine deprivation and argininosuccinate synthetase expression in the treatment of cancer. Int. J. Cancer, 2010; 126: 2762-2772. 
6. Engeland M., Nieland L.J., Ramaekers F.C. et al. Annexin V-affinity assay: a review on an apoptosis detection system based on phosphatidylserine exposure. Cytometry, 1998; 31: 1-9.

7. Feun L., You M., Wu C.J. et al. Arginine deprivation as a targeted therapy for cancer. Curr. Pharm. Des, 2008; 14: 1049-1057.

8. Fukumura D., Kashiwagi S., Jain R.K. The role of nitric oxide in tumour progression. Nature Reviews Cancer, 2006; 6: 521-534.

9. Glazer E.S., Stone E.M., Zhu C. et al. Bioengineered human arginase I with enhanced activity and stability controls hepatocellular and pancreatic carcinoma xenografts. Transnational Oncology, 2011; 4(3): 138-146.

10. Greene L.C., Wagner D.A., Glogowski J. et al. Analysis of nitrate, nitrite and $\left[\mathrm{N}^{15}\right]$ nitrate in biological fluids. Anal. Biochem, 1982; 126: 131.

11. Hernandez C.P., Morrow K., Lopez-Barcons L.A. et al. Pegylated arginase I: a potential therapeutic approach in T-ALL. Blood, 2010; 115: 5214-5221.

12. Huerta S., Chilka S., Bonavida B. Nitric oxide donors: Novel cancer therapeutics (Review). Int. J. of Oncology, 2008; 33: 909-927.

13. Lam T.L., Wong G.K., Chong H.C. et al. Recombinant human arginase inhibits proliferation of human hepatocellular carcinoma by inducing cell cycle arrest. Cancer Letter, 2009; 277: 91-100.

14. Morris S.M. Arginine: beyond protein. Am. J. Clin. Nutr, 2006; 83 (Suppl): 508S-512S.

15. Peterson G.L. A simplification of the protein assay method of Lowry et al. which is more generally applicable. Anal. Biochem, 1977; 83: 346-356.

16. Scott L., Lamb J., Smith S., Wheatley D.N. Single amino acid (arginine) deprivation: rapid and selective death of cultured transformed and malignant cells. Br. J. Cancer, 2000; 83: 800-810.

17. Villalobo A. Nitric oxide and cell proliferation. FEBS, 2006; 273: 2329-2344.

18. Vynnytska-Myronovska B., Bobak Y., Garbe Y. et al. Single amino acid arginine starvation efficiently sensitizes cancer cells to canavanine treatment and irradiation Int. J. Cancer, accepted preprint.

19. Vynnytska B.O., Mayevska O.M., Kurlishchuk Y.V. et al. Canavanine augments proapoptotic effects of arginine deprivation in cultured human cancer cells. Anticancer Drugs, 2011; 22: 148-157.

20. Wang P.G., Xian M., Tang X. et al. Nitric oxide donors: chemical activities and biological applications. Chem. Rev, 2002; 102: 1091-1134.

21. Wheatley D.N., Kilfeather R., Stitt A., Campbell E. Integrity and stability of the citrulline-arginine pathway in normal and tumour cell lines. Cancer Letter, 2005; 227: 141-152.

22. Weiss G., Welner-Felmayer G., Werner E.R. et al. Iron regulates nitric oxide synthase activity by controlling nuclear transcription. J. Ex Med, 1994; 180: 969-976.

\title{
ВПЛИВ ДОНОРА ОКСИДУ АЗОТУ НА ЖИТТЄЗДАТНІСТЬ КЛІТИН ЛЕЙКЕМІЇ ЛЮДИНИ ПРИ ГОЛОДУВАННІ ЗА АРГІНІНОМ
}

\author{
О. І. Чень ${ }^{1,2}$, Л. С. Линів ${ }^{1}$, Н. І. Іеуменцева ${ }^{1}$, \\ М. Л. Барська ${ }^{1}$, Н. О. Сибірна', ${ }^{1,2}$ О. В. Стасик \\ ${ }^{1}$ Інститут біології клітини НАН України, вул. Драгоманова, 14-16, Львів 79005, Україна; \\ 2 Львівський національний університет імені Івана Франка \\ вул. Грушевського, 4, Львів 79005, Україна \\ e-mail: stasyk@cellbiol.Iviv.ua
}

Під час голодування за аргініном у деяких типів пухлинних клітин, нездатних до синтезу аргініну з його попередників, спостерігається пригнічення росту і зни-

ISSN 1996-4536 • Біологічні Студії / Studia Biologica • 2011 • Том 5/№2 • С. 17-28 
ження життєздатності in vitro та in vivo. Проте довготривале голодування за аргініном може призводити до вазоконстрикції та тромбозу в організмі людини внаслідок дефіциту оксиду азоту (NO), який є вазодилататором і дезагрегантом і синтезується з аргініну. Цю проблему можна розв'язати шляхом додавання екзогенних донорів оксиду азоту in vivo, які потенційно можуть мати як проапоптичну, так і антиапоптичну дію на клітини пухлин за умови голодування за аргініном.

У цій роботі було з'ясовано вплив екзогенного донора NO, нітропрусиду натрію (SNP), на життєздатність клітин лейкемії людини Jurkat за умов голодування за аргініном in vitro. Нами встановлено, що голодування за аргініном пригнічує клітинну проліферацію і приводить до швидкого зниження клітинної життєздатності з одночасною індукцією апоптозу. Згідно з визначеними показниками IC50 для SNP і тестів на апоптоз, донор NO у фізіологічних концентраціях не сприяє виживанню пухлинних клітин у середовищі без аргініну. Більш того, цитотоксичність SNP для клітин Jurkat зростає за відсутності аргініну, що вказує на те, що застосування NO донора in vivo може потенційно підвищувати терапевтичний ефект голодування за аргініном.

Ключові слова: голодування за аргініном, оксид азоту, нітропрусид натрію, апоптоз, клітини лейкемії.

\title{
ВЛИЯНИЕ ДОНОРА ОКСИДА АЗОТА НА ЖИЗНЕСПОСОБНОСТЬ КЛЕТОК ЛЕЙКЕМИИ ЧЕЛОВЕКА ПРИ ГОЛОДАНИИ ПО АРГИНИНУ
}

\author{
О. И. Чень',2, Л. С. Лынив ${ }^{1}$, Н. И. Игуменцева', \\ М. Л. Барская ${ }^{1}$, Н. А. Сибирная ${ }^{1,2}$, О. В. Стасык \\ ${ }^{1}$ Институт биологии клетки НАН Украины \\ ул. Драгоманова, 14-16, Львов 79005, Украина \\ ${ }^{2}$ Львовский национальный университет имени Ивана Франко, \\ ул. Грушевского, 4, Львов 79005, Украина \\ e-mail: stasyk@cellibiol.Iviv.ua
}

В условиях отсутствия аргинина у некоторых типов опухолевых клеток, не способных синтезировать аргинин из его предшественников, наблюдается угнетение роста и снижение жизнеспособности in vitro и in vivo. Однако продолжительное истощение аргинина может вызывать вазоконстрикцию и тромбоз в организме человека из-за дефицита оксида азота (NO), который является вазодилататором и дезагрегантом и образуется из аргинина. Эту проблему можно решить путем добавления экзогенных доноров оксида азота in vivo, которые потенциально могут оказывать как проапоптическое, так и антиапоптическое действие на раковые клетки в условиях голодания по аргинину.

В этой работе было исследовано влияние екзогенного донора NO, нитропруссида натрия (SNP), на жизнеспособность клеток лейкемии человека Jurkat в условиях голодания по аргинину in vitro. Нами установлено, что голодание по аргинину угнетает пролиферацию клеток и приводит к быстрому снижению клеточной выживаемости с одновременной индукцией апоптоза. Согласно с определенными показателями IC50 для SNP и тестами на апоптоз, донор NO в фризиологических 
концентрациях не способствует выживанию опухолевых клеток в среде без аргинина. Более того, цитотоксичность SNP для клеток Jurkat возрастает при отсутствии аргинина, что свидетельствует о том, что применение NO донора in vivo потенциально может усиливать терапевтический эффект голодания по аргинину.

Ключевые слова: голодание по аргинину, оксид азота, нитропруссид натрия, апоптоз, клетки лейкемии.

Одержано: 28.07.2011 